\title{
Current Patterns on East Season in The Northern Waters of The Sunda Strait
}

\author{
Ridho L Tondang $^{1 *}$, Kunarso ${ }^{1}$, Jarot Marwoto ${ }^{1}$, Heryoso Setiyono ${ }^{1}$, Hariyadi ${ }^{1}$ \\ ${ }^{1}$ Oceanography Department, Faculty of Fisheries and Marine Science, Diponegoro University \\ Prof. Sudarto St, SH Tembalang Phone. / Fax. (024)7474698 Semarang 50275 \\ Email: kunarsojpr@yahoo.com,jrt.marwoto@gmail.com, \\ ridhotondang@student.undip.ac.id
}

\begin{abstract}
The northern waters of Sunda Strait is the first Indonesian Archipelagic Sea Lanes. (ALKI I) which is an important and a very crowded shipping lane. The first Indonesias Archipelagic Sea Lanes (ALKI 1) connects the marine traffic from Africa, West Australia to South China Sea, Japan and the other way around. Indonesia in determining the archipelagic sea lanes considers several criterias, one of them is the oceanographic condition which is the ocean currents. The purpose of this research is to examine the characteristic of the ocean current pattern in the northern waters of Sunda Strait. The stages of this research include the measurement of field data, field data processing, and hydrodynamics modeling. The research location was determined by purposive sampling method. The determination of the research location follows the path of bathymethry. The result of field measurement is processed then used as data validation of current simulation result of hydrodinamic model. The result of the hydrodynamics model simulation showing the direction of current in northern waters of Sunda Strait moving back and forth following the tidal periods. The direction of the dominant current in northern waters of Sunda Strait is to Northeast (flood current) and Southwest (ebb current). The current velocity in northern waters of Sunda Strait is approximately between $0,0122 \mathrm{~m} / \mathrm{s}$ and $2,590 \mathrm{~m} / \mathrm{s}$. The maximum velocity of the current belongs to several observation points that located in the seabed. This is to be expected due to the impact of Indonesia Through Flow.
\end{abstract}

Keywords: Characteristic of the ocean current pattern, Mounted ADCP Moving Vessel, Hydrodynamics modeling, Northern Waters of Sunda Strait

\section{INTRODUCTION}

The Sunda Strait is a strait connecting the islands of Sumatra and Java Island, as well as connecting between the Java Sea and the Indian Ocean. The Sunda Strait is the Indonesian Archipelagic Sea Lane 1 (ALKI 1) which is an important and very crowded shipping lane. ALKI 1 connects maritime traffic from Africa, Western Australia to the South China Sea, Japan and vice versa. Indonesia in determining archipelagic sea lanes consider several criterias, one of them is oceanographic conditions (Buntoro, 2012).

Knowledge of the characteristics of ocean currents is indispensable for navigation of shipping, planning and development of coastal areas and the construction of coastal structures. Tidal currents are very dominant in the process of circulating sea water in coastal waters. Tidal current is a phenomenon of ups and downs of sea water along with horizontal movement of water that changes direction along the rise and fall of sea water (Chatzirodou, 2017). O'Rourke (2010) opines that tidal currents are a horizontal sea water movement that is influenced by tidal activity. The horizontal motion of sea water mass caused by the phenomenon of the rise and fall of sea water which is called tidal current. The tides arise due to the influence of the attraction of celestial bodies (especially the moon and sun) towards the earth (Hadi, 2010).

The currents that appear in the waters have different dynamics depending on the factors that influence them. Thus, the current pattern may differ in different places. The limitations of measuring instruments for measuring on large areas such as the Sunda Strait become a problem. Based on this problem, flow modeling becomes an alternative choice to fulfill the information needs for long time scales and large areas. The model is a picture that can represents the true state of event that actually happen. Kowalik (2015) uses a high resolution numerical model to explain the uniqueness of tidal currents occurring in the western waters of Fjord Svalbard. Numerical models are used not only to present current conditions in the water, but can also describe the tidal, wave, sediment transport and other conditions (Angeloudis, 2015). Field flow measurements were carried out to obtain the data used 
for the validation of current model simulation results, so that the model can be used as a reference to describe the current conditions in the waters of the North Sunda Strait. The purpose of this study was to examine the pattern of currents in East Season in the Northern waters of Sunda Strait. Map of research location can be seen in Figure 1.
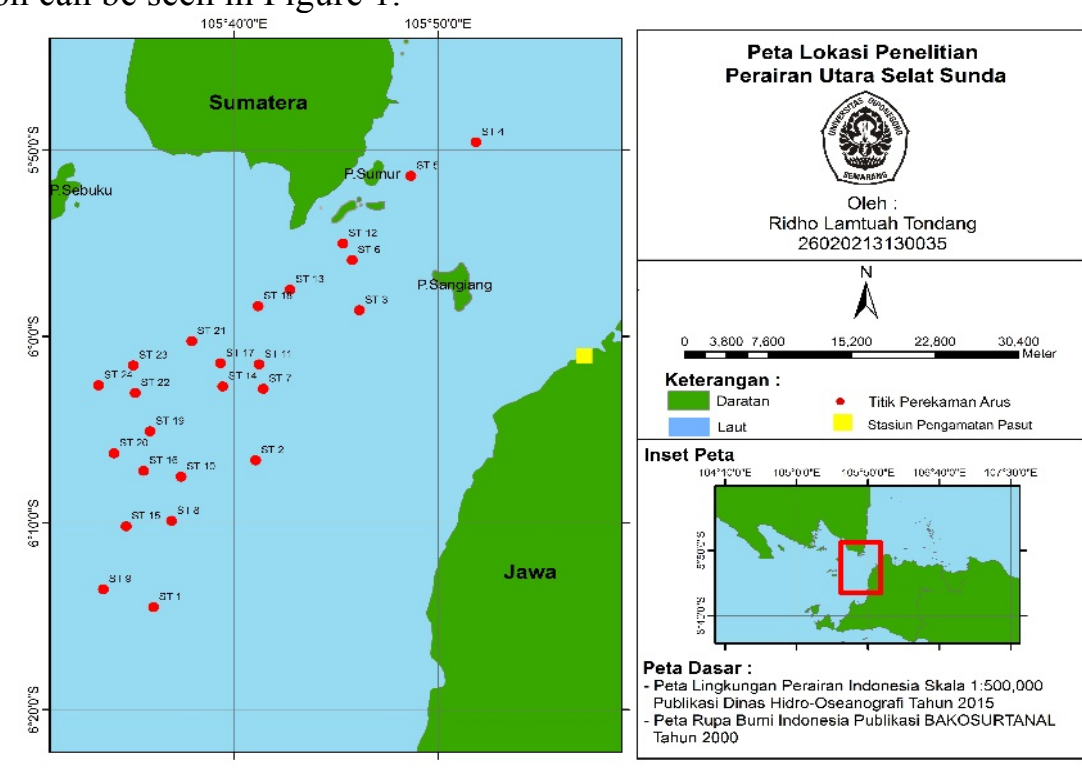

Figure 1. Map of Research Location

\section{METHODOLOGY}

The research materials used in this research are the main data and supporting data. The main data was used in the form of current and tidal data. Supporting data was used in the form of tidal data from forecasting result, wind and bathymetry maps. The measurement of field data is done from $27^{\text {th }}$ to $28^{\text {th }}$ of August 2016. The method which was used in this research is field survey method and numerical modeling. Field survey method is a method of taking data in the field directly. The method of numerical modeling is a method that model the water's characteristics such as conditions in the field, including pattern, velocity and direction of current. The data from field measurement are in the form of current and tidal data. Purposive sampling method was used to detremine the location of research, which based on certain consideration. Determining the location of observations based on conditions can represent the overall condition and effectiveness in data retrieval. The determination of the location of current observation follows the bathymetry sounding for the effectiveness of the motion of the ship.

\subsection{Tidal}

Tidal data for 29 days are processed using admiralty method to generate tidal component values. The result of tidal component is used to determine the Formzal (F) number (Supangat and Susanna, 2003), as follows:

$$
\mathrm{F}=\frac{K_{1}+O_{1}}{M_{2}+S_{2}}
$$

\subsection{Hydrodynamic Modeling}

The 3 dimensional model uses a sigma coordinate transformation approach (DHI Water and Evirontment, 2012). The following is the continuity of the cartesian:

$$
\frac{\partial u}{\partial x}+\frac{\partial v}{\partial y}+\frac{\partial w}{\partial z}=s
$$

The horizontal momentum equation for each of the $\mathrm{x}$ and $\mathrm{y}$ components is as follows: 


$$
\begin{aligned}
& \frac{\partial u}{\partial t}+\frac{\partial u^{2}}{\partial x}+\frac{d v u}{\partial y}+\frac{d w u}{\partial z}=f v-g \frac{\partial \eta}{\partial y}-\frac{1}{\rho o} \frac{\partial \rho o}{\partial x}-\frac{g}{\rho o} \int_{z}^{\eta} \frac{\partial \rho}{\partial x} d z+F u+\frac{\partial}{\partial z}\left(v_{1} \frac{\partial u}{\partial z}\right)+u_{s} s \\
& \frac{\partial v}{\partial t}+\frac{\partial v^{2}}{\partial y}+\frac{d v u}{\partial x}+\frac{d w u}{\partial z}=f u-g \frac{\partial \eta}{\partial y}-\frac{1}{\rho o} \frac{\partial \rho o}{\partial y}-\frac{g}{\rho o} \int_{z}^{\eta} \frac{\partial \rho}{\partial y} d z+F u+\frac{\partial}{\partial z}\left(v_{1} \frac{\partial}{\partial z}\right)+u_{s} s
\end{aligned}
$$

\subsection{Model Validation}

The value of the feasibility of the model outcome for the Cost Function formula is "excellent" for CF values $<1$, "good" for CF values of $1-2$, "tolerable" for CF values $2-3$ and "bad" for CF $>3$ (George et, al., 2010). CF calculation as follows:

$$
C F=\frac{1}{N} \sum_{n=1}^{N} \frac{\left|D_{N}-M_{N}\right|}{\sigma_{D}}
$$

$$
\sigma_{D}=\sqrt{\frac{1}{N} \sum_{n=1}^{N}\left(D_{n}-\bar{D}\right)^{2}}
$$

(6)

Information:

$\mathrm{N} \quad$ : number of observation data

$\mathrm{N} \quad$ : value to $\mathrm{n}$, with $\mathrm{n}=1,2,3, \ldots$.

D : Observation value

M : model value

$\sigma_{D} \quad:$ standard deviation

$\mathrm{D}^{-} \quad$ : average observation data

\section{RESULT AND DISCUSSION}

\subsection{Wind}

Wind rose shows the spread of direction and wind speed in the waters of the Northern Sunda Strait. Wind direction distribution is divided into 8 sections ie north, northeast, east, southeast, south, southwest, west, northwest. The direction of the dominant current is from the east with the occurrence frequency of $28.92 \%$ and from the south-east with the occurrence frequency of $25,30 \%$. The dominant wind speed is $2-3 \mathrm{~m} / \mathrm{s}$ with an incident frequency of $32.93 \%$. The frequency of wind distribution in August is presented in Table 1.

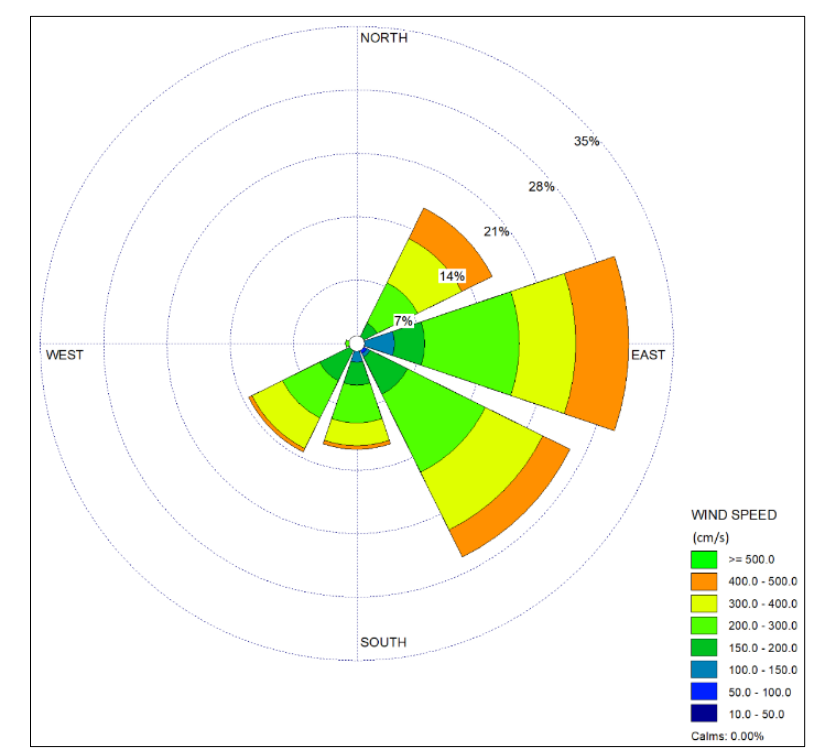

Figure 2. Wind Rose of the North Shore of the Sunda Strait in August 2016 
Table 1. Frequency of Wind Distribution

\begin{tabular}{|c|c|c|c|c|c|c|c|c|c|c|}
\hline No & Arah & $\begin{array}{c}0.1- \\
0.5 \\
(\mathrm{~m} / \mathrm{s})\end{array}$ & $\begin{array}{c}0.5- \\
1 \\
(\mathrm{~m} / \mathrm{s})\end{array}$ & $\begin{array}{c}1- \\
1.5 \\
(\mathrm{~m} / \mathrm{s})\end{array}$ & $\begin{array}{c}1.5- \\
2 \\
(\mathrm{~m} / \mathrm{s})\end{array}$ & $\begin{array}{c}2-3 \\
(\mathrm{~m} / \mathrm{s} \\
)\end{array}$ & $\begin{array}{c}3-4 \\
(\mathrm{~m} / \mathrm{s} \\
)\end{array}$ & $\begin{array}{c}4-5 \\
(\mathrm{~m} / \mathrm{s} \\
)\end{array}$ & $\begin{array}{c}>=5 \\
(\mathrm{~m} / \mathrm{s} \\
)\end{array}$ & $\begin{array}{c}\text { Tota } \\
1 \\
(\%)\end{array}$ \\
\hline 1 & $\begin{array}{l}\text { Utara } \\
\left(337.5^{\circ}-22.5^{9}\right)\end{array}$ & 0 & 0 & 0 & 0 & 0 & 0.42 & 0 & 0 & 0.40 \\
\hline 2 & $\begin{array}{l}\text { Timur Laut } \\
\left(22.5^{\circ}-67.5^{\circ}\right)\end{array}$ & 0 & 0.42 & 0.42 & 1.67 & 5 & 5.42 & 3.75 & 0 & $\begin{array}{c}16.0 \\
6\end{array}$ \\
\hline 3 & $\begin{array}{l}\text { Timur } \\
\left(67.5^{\circ}-112.5\right)\end{array}$ & 0 & 0.83 & 3.33 & 3.33 & $\begin{array}{c}10.4 \\
2\end{array}$ & 6.25 & 5.83 & 0 & $\begin{array}{c}28.9 \\
2\end{array}$ \\
\hline 4 & $\begin{array}{l}\text { Tenggara } \\
\left(112.5^{\circ}-157.5^{\circ}\right)\end{array}$ & 0 & 1.25 & 0.42 & 4.58 & 9.58 & 7.08 & 3.33 & 0 & $\begin{array}{c}25.3 \\
0\end{array}$ \\
\hline 5 & $\begin{array}{l}\text { Selatan } \\
\left(157.5^{\circ}-202.5^{\circ}\right)\end{array}$ & 0 & 0.42 & 1.67 & 2.5 & 4.17 & 2.5 & 0.42 & 0 & $\begin{array}{c}11.2 \\
5\end{array}$ \\
\hline 6 & $\begin{array}{l}\text { Barat Daya } \\
\left(202.5^{\circ}-2479\right)\end{array}$ & 0 & 0 & 0.83 & 3.75 & 4.58 & 3.75 & 0.42 & 0 & $\begin{array}{c}12.8 \\
5\end{array}$ \\
\hline 7 & $\begin{array}{l}\text { Barat } \\
\left(247.5^{\circ}-292.5^{\circ}\right)\end{array}$ & 0 & 0 & 0.42 & 0.42 & 0.42 & 0 & 0 & 0 & 1.20 \\
\hline 8 & $\begin{array}{l}\text { Barat Laut } \\
\left(292.5^{\circ}-337.5\right)\end{array}$ & 0 & 0.42 & 0 & 0 & 0 & 0 & 0 & 0 & 0.40 \\
\hline & $\begin{array}{l}\text { Sub-Total } \\
\text { Calm } \\
\text { Missing } \\
\text { Total }\end{array}$ & 0 & 3.21 & 6.83 & 15.66 & $\begin{array}{c}32.9 \\
3\end{array}$ & $\begin{array}{c}24.5 \\
0\end{array}$ & $\begin{array}{c}13.2 \\
5\end{array}$ & 0 & $\begin{array}{c}96.3 \\
9 \\
0 \\
3.61 \\
100 \\
\end{array}$ \\
\hline
\end{tabular}

\subsection{Ocean Current}

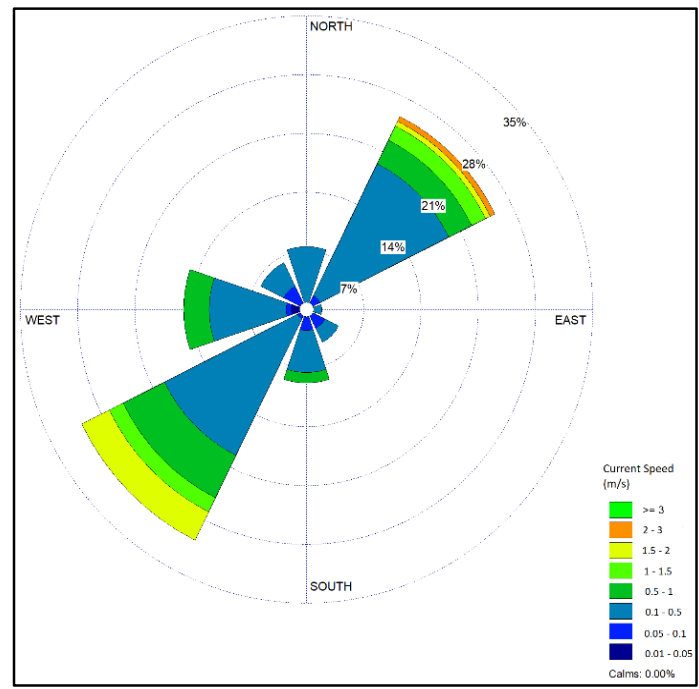

a)

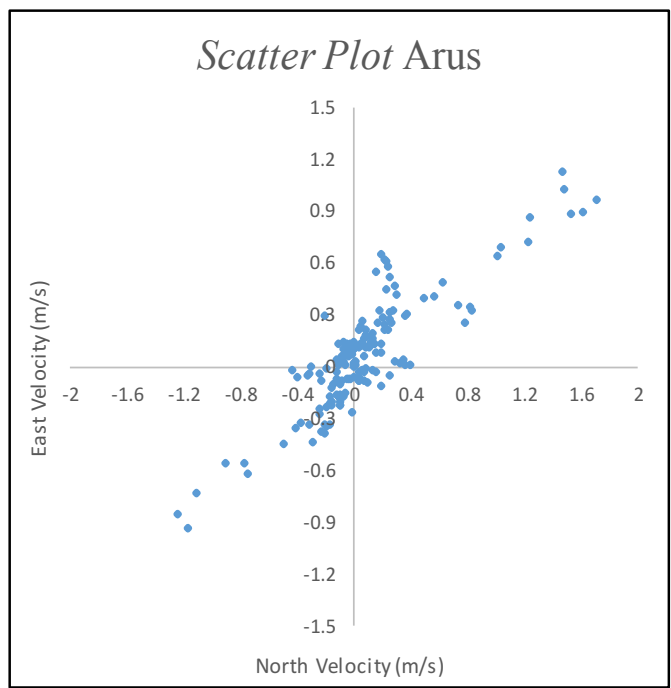

b)

Fig 3. a) Current Rose; b) Scatter Plot of the North Waters of the Sunda Strait

The direction of dominant current in the waters of the Northern Sunda Strait is to the Southwest and Northeast with the occurrence frequency of $30.62 \%$ and $25.62 \%$. The dominant current velocity is $0.1-0.5 \mathrm{~m} / \mathrm{s}$ with an incidence frequency of $63.12 \%$. The scatter plot shows that the current is moving in a varying direction. The pattern of eliphesis shows that the dominant direction of the current is influenced by the presence of tides in the study area, the scatter plot describes the distribution of the number of current directions in each quadrant. The frequency of current distribution is presented in Table 2. 
Table 2. Distribution of Current Frequency

\begin{tabular}{|c|c|c|c|c|c|c|c|c|c|c|}
\hline No & Arah & $\begin{array}{c}0.01- \\
0.05 \\
(\mathrm{~m} / \mathrm{s}) \\
\end{array}$ & $\begin{array}{c}0.05- \\
0.1 \\
(\mathrm{~m} / \mathrm{s}) \\
\end{array}$ & $\begin{array}{c}0.1- \\
0.5 \\
(\mathrm{~m} / \mathrm{s}) \\
\end{array}$ & $\begin{array}{c}0.5- \\
1 \\
(\mathrm{~m} / \mathrm{s}) \\
\end{array}$ & $\begin{array}{c}1- \\
1.5 \\
(\mathrm{~m} / \mathrm{s}) \\
\end{array}$ & $\begin{array}{c}1.5- \\
2 \\
(\mathrm{~m} / \mathrm{s}) \\
\end{array}$ & $\begin{array}{c}2-3 \\
(\mathrm{~m} / \mathrm{s} \\
)\end{array}$ & $\begin{array}{c}>=3 \\
(\mathrm{~m} / \mathrm{s} \\
)\end{array}$ & $\begin{array}{c}\text { Tota } \\
1 \\
(\%) \\
\end{array}$ \\
\hline 1 & $\begin{array}{l}\text { Utara } \\
\left(337.5^{\circ}-22.5^{9}\right)\end{array}$ & 0 & 0.62 & 6.87 & 0 & 0 & 0 & 0 & 0 & 7.5 \\
\hline 2 & $\begin{array}{l}\text { Timur Laut } \\
\left(22.5^{\circ}-67.5^{\circ}\right)\end{array}$ & 0 & 1.87 & 17.5 & 3.12 & 1.87 & 0.62 & 0.62 & 0 & $\begin{array}{c}25.6 \\
2\end{array}$ \\
\hline 3 & $\begin{array}{l}\text { Timur } \\
\left(67.5^{\circ}-112.5^{\circ}\right)\end{array}$ & 0 & 0.62 & 1.25 & 0 & 0 & 0 & 0 & 0 & 1.87 \\
\hline 4 & $\begin{array}{l}\text { Tenggara } \\
\left(112.5^{\circ}-157.5^{\circ}\right)\end{array}$ & 0.62 & 1.87 & 1.87 & 0 & 0 & 0 & 0 & 0 & 4.37 \\
\hline 5 & $\begin{array}{l}\text { Selatan } \\
\left(157.5^{\circ}-202.5^{9}\right)\end{array}$ & 0 & 2.5 & 5 & 1.25 & 0 & 0 & 0 & 0 & 8.75 \\
\hline 6 & $\begin{array}{l}\text { Barat Daya } \\
\left(202.5^{\circ}-247.5^{2}\right)\end{array}$ & 0.62 & 0.62 & 18.12 & 5.62 & 1.87 & 3.75 & 0 & 0 & $\begin{array}{c}30.6 \\
2\end{array}$ \\
\hline 7 & $\begin{array}{l}\text { Barat } \\
\left(247.5^{\circ}-292.5^{9}\right)\end{array}$ & 1.87 & 0.62 & 9.37 & 3.12 & 0 & 0 & 0 & 0 & 15 \\
\hline 8 & $\begin{array}{l}\text { Barat Laut } \\
\left(292.5^{\circ}-337.5^{\prime}\right)\end{array}$ & 0.62 & 2.5 & 3.12 & 0 & 0 & 0 & 0 & 0 & 6.25 \\
\hline & Sub-Total & 3.75 & 11.25 & 63.12 & 13.12 & 3.7 & 4.37 & 0.62 & 0 & 100 \\
\hline & $\begin{array}{l}\text { Calm } \\
\text { Total }\end{array}$ & & & & & & & & & $\begin{array}{c}0 \\
100\end{array}$ \\
\hline
\end{tabular}

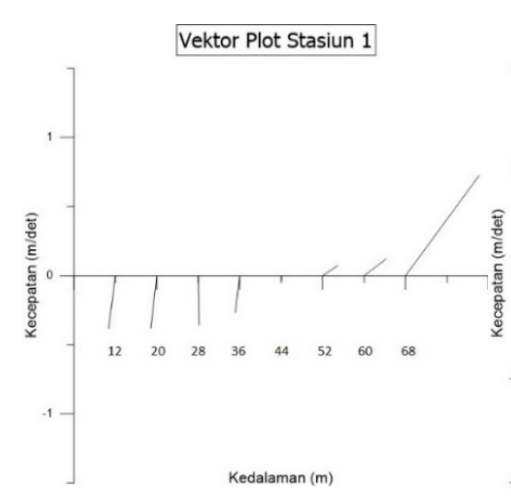

a)

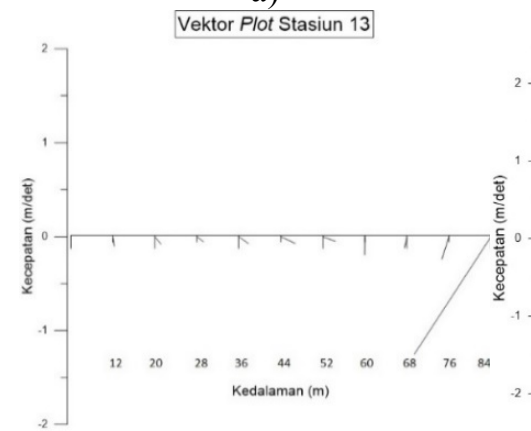

d)

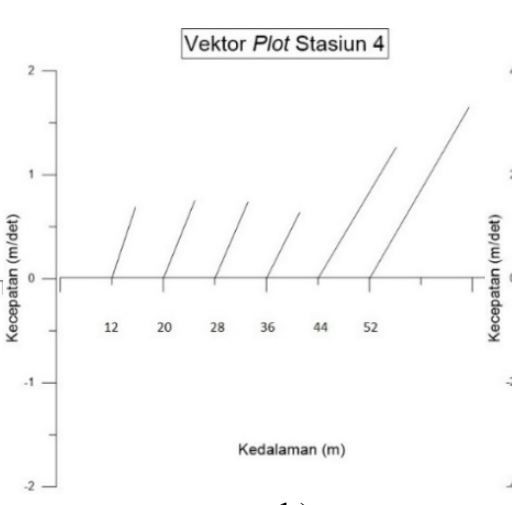

b)

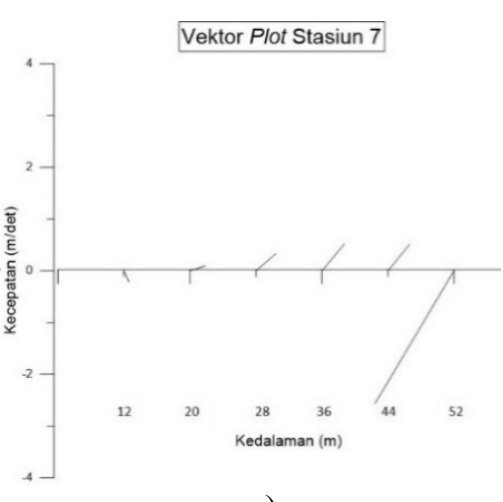

c)

Vektor Plot Stasiun 24
Vektor Plot Stasiun 18

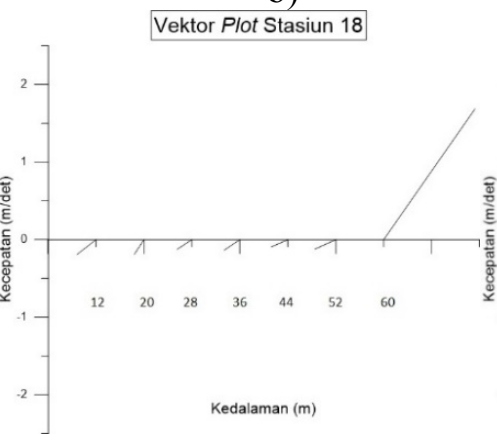

e)

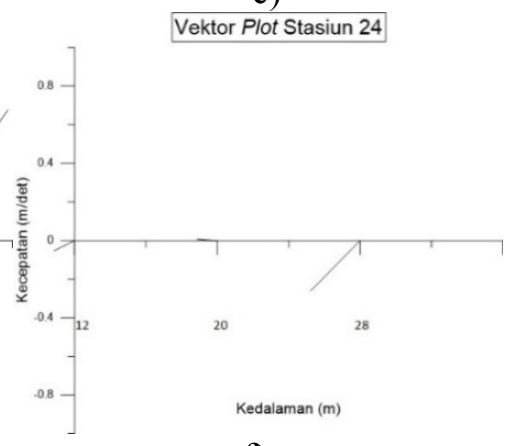

f)

Figure 4. Vector Plot Flow a) Station 1; b) Station 4; c) Station 7; d) Station 13; e) Station 18; f) Station 24 
The straight line on the plot vector shows the dominant direction of the current of the research area and the length of the line means the current velocity, the longer the line on the diagram the greater the velocity of the current. Measurement of ocean currents on the date indicates that the direction of the current is dominant to the Southwest and Northeast. The highest current velocity is at the bottom of the waters, shown by 20 stations.

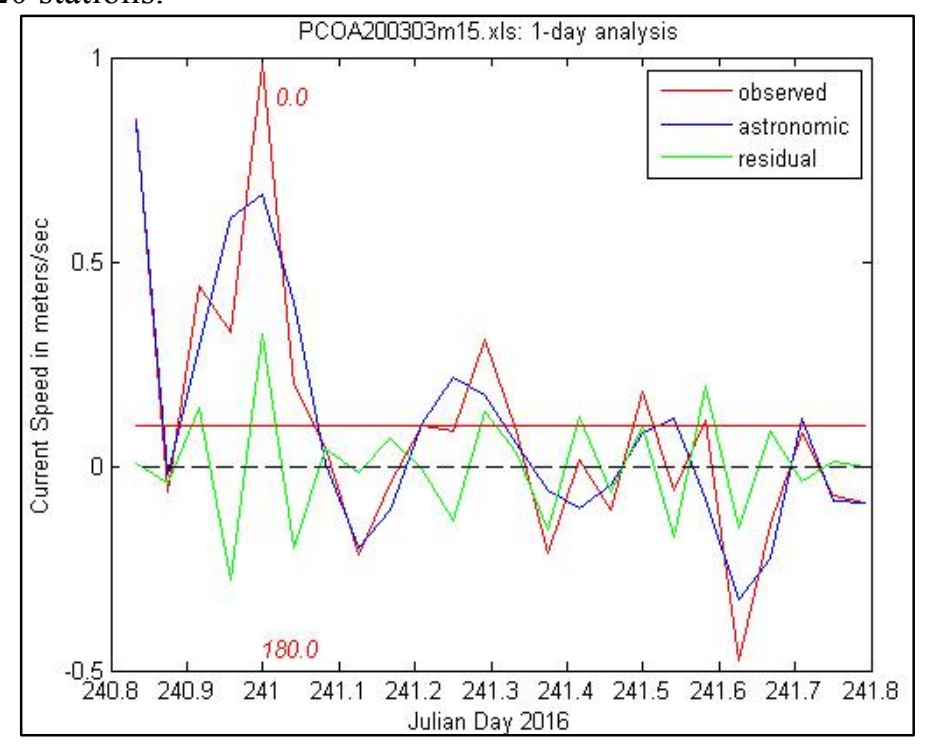

Figure 5. Graph of Flow of Tides and Residues

Based on field observation current analysis, graph of residual and elliptical currents is generated. Figure 5 shows an observed field flow chart having a pattern and magnitude that follows the tidal current. The type of dominant current generator in the north waters of the Sunda Strait is the tidal current of $52 \%$.

\subsection{Tidal}

The tidal observation for 29 days obtained by tidal constant is shown in Tables 3 and 4 .

Table 3. Tidal Components Station Banten, Sunda Strait

\begin{tabular}{ccccccccccc}
\hline Component & S0 & M2 & S2 & N2 & K1 & O1 & M4 & MS4 & K2 & P1 \\
\hline A $(\mathrm{cm})$ & 59 & 27 & 12 & 5 & 12 & 6 & 1 & 0 & 3 & 4 \\
Phase $\left({ }^{\circ}\right)$ & & 249 & 66 & 144 & 178 & 355 & 168 & 43 & 66 & 178 \\
\hline
\end{tabular}

Table 4. Value of Harmonic Constant Tidal Station Banten

\begin{tabular}{lcc}
\hline F (Formhzal) & 0.442 & \\
HHWL & 116 & semi diurnal \\
HWL & 98 & \\
LLWL & 3 & \\
LWL & 20 & \\
MSL & 59 & \\
\hline
\end{tabular}

Tidal type determinants in Sunda Strait waters is the value of Formhzal $(F)=0.442$ so that the Sunda Strait waters have double tangent mixed daily tidal type. Hadi (2010) describes this type in a day occurs twice and twice ups. The graph is presented in Figure 6 below. 


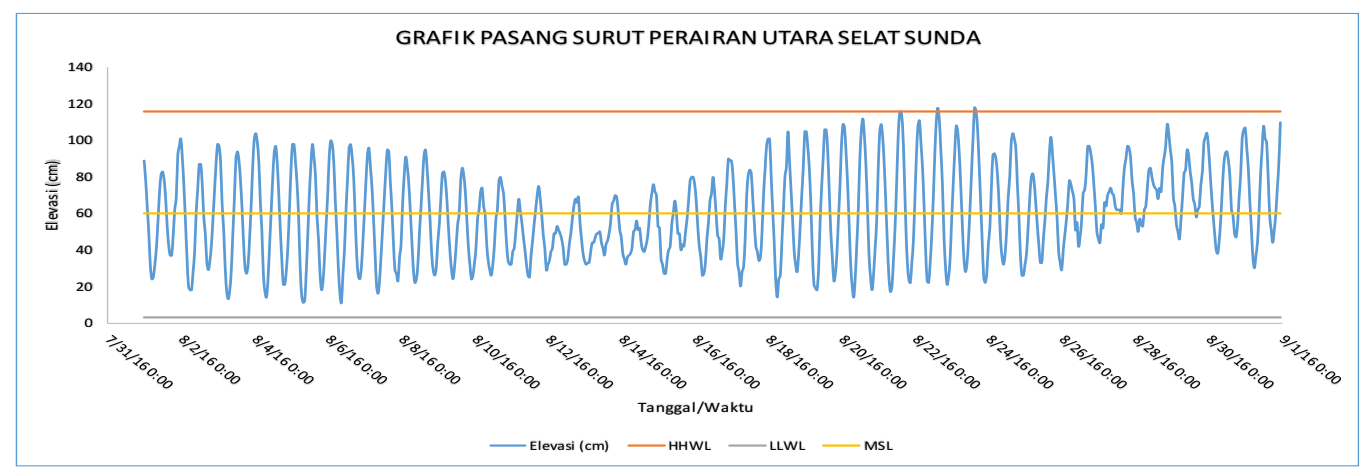

Figure 6. Tidal Elevation Charts 1-31 August 2016.

\section{Field Data Flow Validation Results and Model Flow}

Validation is done by comparing the data of current model with current measurement data in the field which is done based on same point and time. Validated data are the $u$ and $v$ component data. Validation results in the form of CF values shown in Table 5.

\section{Model Flow Simulation}

The current patterns are depicted in 3 Layers i.e Layer 1 (12 m), Layer $2(44 \mathrm{~m})$, and Layer 3 $(84 \mathrm{~m})$. The captured layer is assumed to be a Layer representing the water depth of the surface, middle and bottom. The result of current modeling is shown in Fig. 6-8.

\begin{tabular}{ccc}
\multicolumn{3}{c}{ Table 5. CF Value of Component U and V Flow } \\
\hline \multirow{2}{*}{ Layer } & $\begin{array}{c}\text { Nilai CF Komponen } \\
\text { U }\end{array}$ & $\begin{array}{c}\text { Nilai CF Komponen } \\
\text { V }\end{array}$ \\
\hline 1 & 0.535 & 0.685 \\
2 & 0.431 & 0.536 \\
3 & 0.526 & 0.452 \\
4 & 0.512 & 0.463 \\
5 & 0.566 & 0.538 \\
6 & 0.698 & 0.604 \\
7 & 0.782 & 0.687 \\
8 & 0.767 & 0.722 \\
9 & 0.479 & 0.485 \\
10 & 0.438 & 0.569 \\
\hline
\end{tabular}

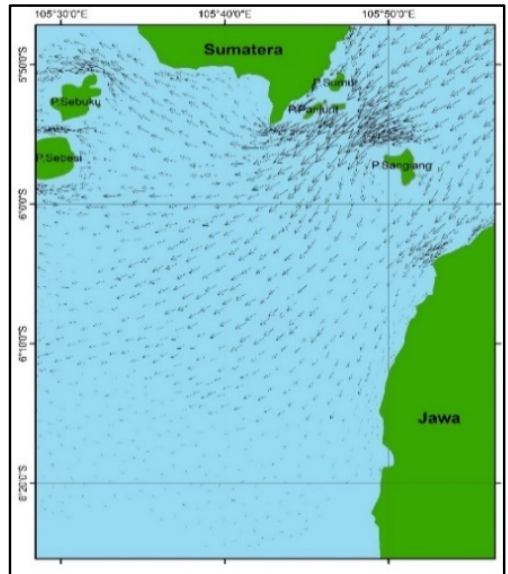

a)

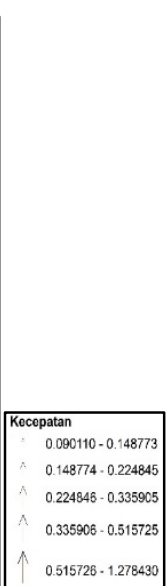

$0.515726 \cdot 1.278430$

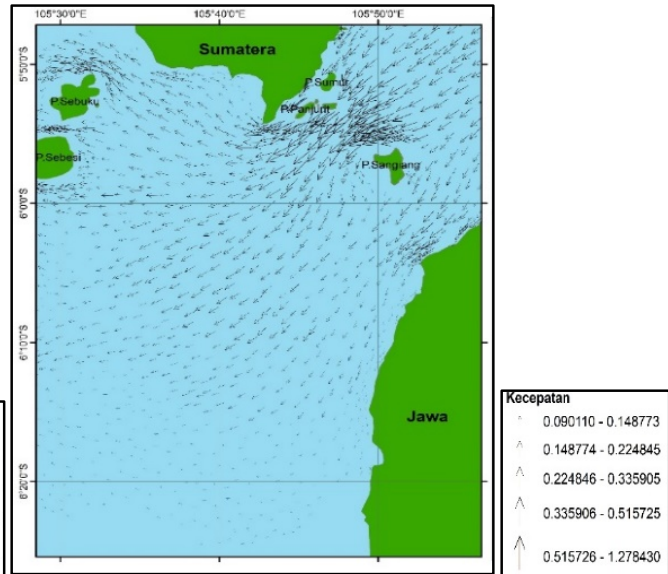

b)

Fig 7. Map of Flow Pattern $12 \mathrm{~m}$ At Condition a) Towards Tidal Down, b) Down to Tide 


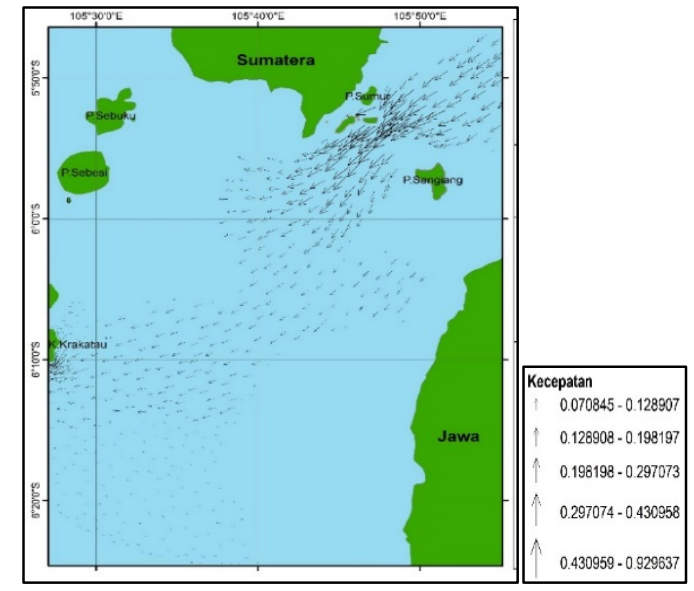

a)

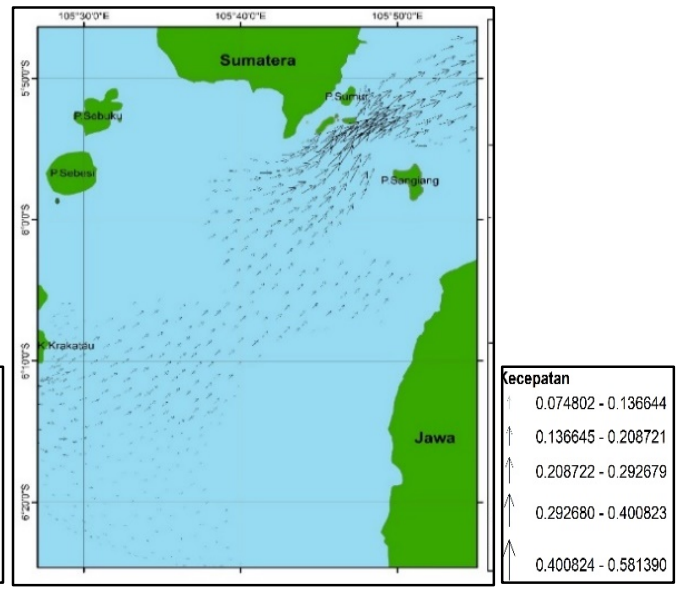

b)

Fig 8. Map of $44 \mathrm{~m}$ Depth Flow Pattern Under Condition a) Towards Tidal Down, b) Down to Tide

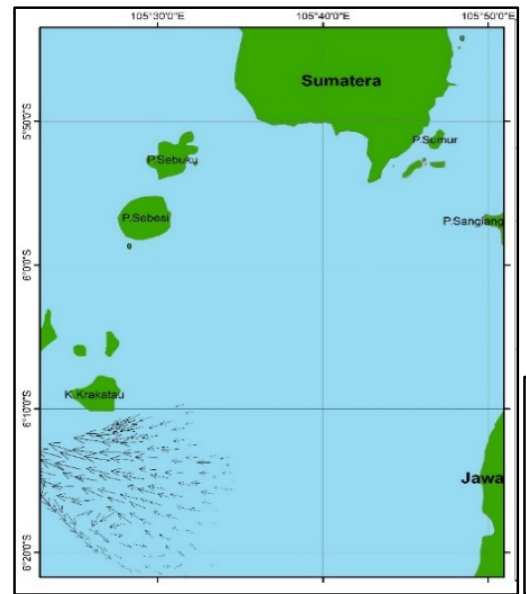

a)

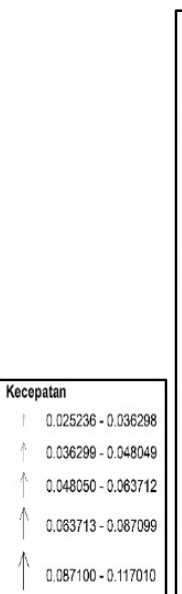

$0.087100-0.117010$

b)

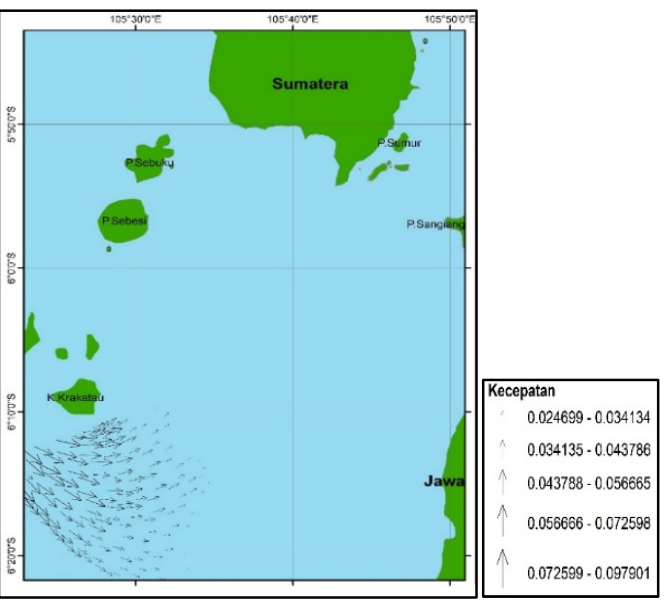

Fig 9. Flow Pattern Map 84 m At Condition a) Towards Towards; b) Down to Tide

\section{Discussion}

The characteristic of the current pattern in the Northern waters of the Sunda Strait consists of the direction of the dominant current, the velocity and the type of current movement. The direction of the dominant current in the Northern waters of Sunda Strait is to the Northeast and the Southwest (Figure 3a). The dominant current movement to the Northeast and Southwest is influenced by many factors such as wind and tidal. The movement of currents to the Northeast and the Southwest is reinforced by winds blowing from the Southwest and Northeast. The wind velocity that blows from the Northeast ranges from $0.5-5 \mathrm{~m} / \mathrm{s}$ with an incidence frequency of $16.06 \%$, while the wind velocity that blows from the Southwest ranges from $1-5 \mathrm{~m} / \mathrm{s}$ with an incidence frequency of $12.85 \%$ (Figure 2 and Table 1). Hadi (2010) describes the stress of the wind that works on the surface of the sea will encourage water on the surface to form surface currents, surface current patterns follow the pattern of surface wind.

The dominant current movement towards the Northeast and the Southwest when associated with tidal activity is indicative of the dominant current associated with the tides (Figure 3b). This indicates that the type of current in the northern waters of the Sunda Strait is the tidal current. The separation graph (Fig. 5) confirms that the dominant current in the northern waters of the Sunda Strait is the tidal current, visible from the field measurement current line which almost coincides with the astronomic current line (tide). Supangat and Susanna (2003) explain that vertical water movement associated with the rise and fall of tidal, accompanied by horizontal water movement is called tidal current. Sutirto and 
Trisnoyuwono (2014) also add tidal currents are horizontal motion of water to and away from the coast along with the rise and fall of sea water (tides) caused by the tidal power generation.

The current model (Figure 6-8) is the result of the model simulation that has been corrected with the current data from the field measurement using Cost Function (CF) calculation to determine the error between the two data so that the model data can be trusted accurately (Table 5). The current model illustrates the direction of currents at the variations of depth indicating the direction of the dominant current in the Northern waters of Sunda Strait moving to the Southwest and Northeast. This provides a strong indication that the pattern of currents in the Northern waters of Sunda Strait is dominantly influenced by tidal currents. The movement of currents at a depth of $12 \mathrm{~m}$ (surface) during tidal conditions tends to move out of the Sunda Strait towards the Indian Ocean (Fig. 7a), while at low tide the tide tends to move from the Indian Ocean into the Sunda Strait (Figure 7b). Current movement at water depth $44 \mathrm{~m}$ (center) and $84 \mathrm{~m}$ (base), designate same movement pattern (Fig. 7-8). The same pattern of current movement in this depth variation indicates that the type of tidal current movement in the Northern waters of the Sunda Strait is hydraulic. Hadi and Radjawane (2009) explains that astronomical and topographical styles (coastal geometry and depth) give rise to certain current patterns in the waters. In high tide condition, the current moves into the strait and at low tide reverses outward from the strait and usually occurs in the strait that connects two unrelated water bodies called hydraulic tidal current. The pattern of tidal current movement in the research area occurs twice a day. Tidal current movements related to tidal types in the Northern waters of Sunda Strait are the double tidal daily (Table 10), so that the tides and lows occur as much as two times each but have different periods. Neil (2015) explains that the mixed-type tidal leads to semidiurnal having two tides and two neaps where each has a different period.

Current velocity in the Northern waters of Sunda Strait ranges from $0.012-2.590 \mathrm{~m} / \mathrm{s}$ (Table 2). Variations in current velocity in the Northern waters of Sunda Strait, besides from being influenced by the movement condition of the data every 10 minutes, are also influenced by the base currents. Small current velocities in the middle layer / encounter two opposing currents, occur also because of the friction between the surface current with the base current, so that the friction of the opposite current is mutually impeding speed rate. The simulation result of model is between $0.024-1.278 \mathrm{~m} / \mathrm{s}$ (Fig 6-8). The vector shows the direction and velocity of currents occurring in the simulated area, the longer the vector shows the greater the current velocity. A large current velocity is seen in the area around Sangiang Island, Sumur Island, and Panjurit Island, where this area is a constrigency area in the Sunda Strait (Fig 6).

The maximum current velocity at each station is found almost at the bottom of the water, shown by 20 stations (Figure 4). The maximum speed occurring at the bottom of the water is suspected due to the influence of ARLINDO. Jumarang (2013) explains that the Sunda Strait is an ARLINDO line aside from the main crossroads such as the Lombok Strait, the Ombai Strait, and the Timor Sea. This is also reinforced by Wyrtki's (1961), which states that the Sunda Strait and the Malacca Strait is the waterway between the Indian Ocean and the Pacific Ocean, even though it's a small way due to the narrowness of the straits.

\section{CONCLUSION}

The dominant surface current in the northern waters of the Sunda Strait is the tidal current. The direction of the current movement in the high tide to low tide conditions is to the Southwest, while at low tide to high tide condition, the direction of the current is to Northeast. The type of tidal current movement in the Northern waters of Sunda Strait is hydraulic. The movement of alternating currents from the Northeast to the Southwest and vice versa as tidal movements occurs twice a day (tidal mixed double-skew daily).

Current velocity in the northern waters of the Sunda Strait ranges from $0.012 \mathrm{~m} / \mathrm{s}-2.590 \mathrm{~m} / \mathrm{s}$, where the maximum velocity at each observation point / station is at the bottom of the waters. 


\section{REFERENCES}

Angeloudis, A., Reza Ahmadian, Roger A. Falconer and Bettina Bockelmann-Evans. 2015. Numerical model Simulations for Optimisation of Tidal lagoon Schemes. Elsevier. Cardiff Univ. of Engineering, Cardiff, p.522 (abstract).

Buntoro, K. 2012. Alur Laut Kepulauan Indonesia (ALKI). Sekolah Staf dan Komando TNI AL(SESKOAL), Jakarta, 330 hlm.

Chatzirodou, A., Harshinie K., and Dominic E. Reeve. 2017. Modelling 3D Hydrodynamic Governing Island-Associated Sandbanks in a Proposed Tidal Stream Energy Site. Elsevier. Zienkiewicz Centre for Computational Engineering College of Engineering. Swansea Univ., Swansea, p.79 (abstract).

Danish Hydraulic Institute Water and Environment (DHI). 2012. Manual Mike 21 Flow Model Hydrodinamic Module, Scientific Background. DHI Waters \& Environment, Horsholm, Denmark.

George, MS., Bertino, L., Johannessen, OM., and Samuelsen, A., 2010. Validation of a Hybrid Coordinate Ocean Model for The Indian Ocean. Journal of Operational Oceanography. 1(1) : Nansen Enviromental And Remote Sensing Center, Bergen, p. 25 (absctract).

Hadi, Safwan. 2010. Pengantar Oseanografi Fisis. Institut Teknologi Bandung, Bandung, 218 hlm.

Hadi, S. dan Radjawane, I. M. 2009. Arus Laut. Ganesha ITB Bandung, Bandung, 160 hlm.

Jumarang, M. Ishak dan Nining S. Ningsih. 2013. Transpor Volume Massa Air di Selat Sunda Akibat Interaksi Enso, Monsun dan Dipole Mode. Prosiding Semirata FMIPA Universitas Lampung (abstrak).

Kowalik, Z., Aleksey Marchenko and Dmitry Brazhnikov. 2015. Tidal Current in The Western Svalbard Fjords. Elsevier. Univ. of Alaska Fairbanks dan The Univ. Centre in Svalbard, p.318 (abstract).

Neill, Simon P., M. Reza Hashemi and Matt J. Lewis. 2015. Tidal Energy Leasing and Tidal Phasing. Elsevier. Bangor Univ. of Ocean Sciences and Univ. of Rhode Island of Ocean Engineering, Menai Bridge, p.580 (abstract).

O'Rourke, Fergal, Fergal Boyle and Anthony Reynolds. 2010. Tidal Current Energy Resource Assessment in Ireland: Current Status and Future Update. Elsevier. Department of Mechanical Engineering. Dublin Institute of Technology, Dublin, p.3206 (abstract).

Supangat, A. dan Susanna. 2003. Pengantar Oseanografi. BRKP, Jakarta, 273 hlm.

Sutirto, S.T., M.T. dan Trisnoyuwono, D.,S.T., M.T. 2014. Gelombang dan Arus Laut Lepas. Graha Ilmu, Yogyakarta, $131 \mathrm{hlm}$.

Wyrtki, K. A. 1961. Scientific Results of Marine Investigations of the South China Sea and Gulf of Thailand 1959-1961. Naga Report II, The University of California. Scripps Institution of Oceanography, La Jolla. California. 